\title{
Technological mediation in the future of experiential tourism
}

\section{Ellis Urquhart}

Ellis Urquhart is based at the Tourism and Languages Subject Group, Edinburgh Napier University, Edinburgh, UK.
Received 14 April 2019 Revised 25 April 2019 Accepted 29 April 2019

(c) Ellis Urquhart. Published in Journal of Tourism Futures. Published by Emerald Publishing Limited. This article is published under the Creative Commons Attribution (CC BY 4.0) licence. Anyone may reproduce, distribute, translate and create derivative works of this article (for both commercial and non-commercial purposes), subject to full attribution to the original publication and authors. The full terms of this licence may be seen at http:// creativecommons.org/licences/by/ 4.0/legalcode

\begin{abstract}
Purpose - The purpose of this paper is to consider the role that technology may play in the future of experiential tourism. This viewpoint paper begins to question future developments in technological mediation and how these may challenge the author' view of experiences and their construction in a period of immense and rapid technological development.

Design/methodology/approach - This is a short viewpoint paper driven by theoretical perspectives in the existing academic literature and the author's personal stance on the future of experiential tourism.

Findings - This paper suggests that while there is considerable research into the role and application of technology within tourism, there is a lack of future-orientated debate. The views expressed within the paper argue that three potential directions exist for the future of technological mediation in experiential tourism: mass acceptance and customisation; experiential convergence or "rewinding the clock", each with significant implications for the management of technological mediation in experiential tourism.

Originality/value - The paper provides an initial insight into future directions of the tourism industry in a period of immense technological development. Based on existing theoretical perspectives, these viewpoints indicate three potential routes for the industry and act as a catalyst for further dialogue within tourism scholarship.
\end{abstract}

Keywords Technology, Mediation, Experience, Tourism

Paper type Viewpoint

\section{Introduction}

The rapid development of technology has revolutionised the tourism experience. As suggested by Benckendorff et al. (2014), contemporary technology can play a wide variety of roles within travel and tourism. It can enable and facilitate, enhance and protect, or act as a substitute for elements of the experience that are lacking. The adoption of technology within tourism has also inspired changes in consumer behaviour. Coussement and Teague (2013) argued that innovations in technology have led to constantly connected consumers which have reconfigured the relationship between travellers and tourism providers. This has inspired organisations, and the wider industry, to consider the role of technology as a constant mediator in the tourism experience. For the purpose of this paper, mediation refers to the various points of interaction (both tangible and intangible, personal and non-personal) which broker an engaging and quality tourism experience (Jennings and Weiler, 2005). Increasingly, however, this mediation has taken a technological form through mobile, handheld, virtual or internet-based platforms (Tussyadiah and Fesenmaier, 2009). This, in turn, has made it particularly challenging to predict how the future use and management of mediation may impact the industry.

The range of technological mediation in tourism is significant and has grown to include mobile-enabled platforms to provide information (Morosan and DeFranco, 2016; Wang et al., 2014); fixed touchpoints within tourism experiences such as visitor attractions (Rey and Casado-Neira, 2013); e-services to facilitate traveller research, booking and management (Barrutia and Gilsanz, 2009); social media and user-generated content (Haddouche and Salomone, 2018; Hvass and Munar, 2012); and virtual/augmented reality to add additional layers to tourism experiences in destinations (Jung et al., 2015; Scarles et al., 2016; 
Younes et al., 2017). However, despite the growth in technological innovation, there is a surprising lack of scholarly discussion on the future directions and associated implications for the travel and tourism industry.

While significant academic discussion has revolved around the role of technology and current innovations in the sector, less has been considered from a futures perspective. This is interesting considering the wide-reaching implications of technology for future tourism experiences. Particularly relevant to this Special Issue is a need for academic discussions to consider future directions for technological mediation in tourism. In this viewpoint paper, an initial discussion of existing technological mediation perspectives acts as a theoretical framework to begin the debate. Thereafter, three future directions have been identified and considered to encourage conversations into the future of technological mediation in tourism experiences.

\section{Technological mediation in tourism experiences}

An understanding of the importance of technological mediation is well established in the literature. From a service management perspective, Schumann et al. (2012) provided a distinction between services which were fully automated (such as self-service platforms) and delivered services (where technology exists alongside other features). These delivered services use technology for customisation, personalisation and to engage consumers in co-creative activity - which can have significant effects on experiential value (Buonincontri et al., 2017; Mathis et al., 2016). Within tourism scholarship, Tussyadiah (2014) argued that effective control over how tourists interact with the physical, social and media elements of a tourist destination is a fundamental feature of experience design. This control can be enacted through various forms of mediation. This is supported by Gretzel and Jamal (2009), who suggested that emerging "creative tourists" are empowered to construct their experiences iteratively through engagement with not only physical structures but also interactive technologies. Such perspectives reignite the need to conceptualise technology, not only as a tool but as a powerful mediating force that can have significant influence over tourism experiences.

Critical to this discussion is an awareness of the diversity in technological mediation in the tourism industry. Neuhofer et al. (2014) identified a hierarchy of technology-enhanced tourism experiences from conventional (low technology-enabled and staged experiences) to technology-empowered experiences (high interactivity and pervasive technology-use) to benchmark tourism organisations for their technology provision and experiential aspirations. As the industry is diverse and technology-use within the various sectors of travel and tourism are varied, there is no singular way to predict technological mediation throughout the collective industry. However, the directions discussed later in this paper have been kept inclusive to acknowledge the variety that exists within the industry.

The powerful mediating role of technology has seen considerable attention in the academic literature, particularly for its implications for enriching tourism experiences. Wan (2018) suggested integrating the psychological components of memorable, meaningful experiences into technology design so that platforms better reflect the needs and wants of consumers. Similarly, Zhang et al. (2015) suggested that environmental stimuli (afforded by interactive technology) can lead to customer learning, social integration and hedonic value within an experience. Such perspectives advocate the need to view technology as a means, to not only achieve business benefits but also as a fundamental component of the consumer experience. This is particularly true in recent research that debates the importance of technological mediation for targeting and engaging certain audiences, such as Generation Y (Zhang et al., 2017).

However, there are complexities associated with technological mediation. For example, Lu et al. (2015) suggested that mobile-enabled applications in the tourism experience can have an empowering effect for consumers through enhanced access to information and control over elements such as research, bookings and sharing platforms. However, Minghetti and Buhalis (2010) argued that although consumers in the developed world have ready access to technology, this does not imply that they use it wisely. Lack of trust, knowledge, skills or capabilities can hinder consumer engagement with technological platforms and as such may compromise the extent to which they feature within the experience. As a mediating force, it is therefore unsurprising that the 
industry has diverted significant capital into designing innovative technologies; however, there are inherent challenges in relying too heavily on technology as a sole mediator.

Beyond the experiential benefits of enhanced technological mediation, there are operational advantages in adopting such technologies. Namely, there are potential efficiency benefits (Alford and Clarke, 2009; Buhalis and Law, 2008), value-adding prospects (Chathoth et al., 2016; Peña et al., 2014) and opportunities to protect core resources - such as cultural heritage (Gombault et al., 2016; tom Dieck and Jung, 2017). The proliferation of academic research in these areas is reflective of its growing importance within the tourism industry; however, more focus is needed to consider future directions.

\section{Future directions}

Despite the plethora of academic arguments surrounding technological mediation in tourism, this area is primed for further debate from a futures perspective. In considering where technology and its management may proceed in future generations, the following three directions, illustrated in Figure 1, provide avenues to expand current discussions. As technology continues to become advanced, intuitive and reactive, the industry may choose to undertake mass acceptance and customisation to utilise technological mediation to its fullest through adoption and investment. Alternatively, the industry may elect to adopt a middle-ground approach through experiential convergence, with the further blurring of the division between the physical and virtual tourism experience. Finally, and perhaps most controversially, may be the industry's choice to "rewind the clock" and actively remove technological mediation from certain experiences. The following discussion considers each of these three directions to provide a proving ground for future academic debate.

\section{Mass acceptance and customisation}

The first direction which the industry may elect to follow is mass acceptance and customisation. Driven by a reaction to technological trends occurring in society, this direction would reposition technology as the main influencer within experiential tourism. As such, tourism providers would need to accept and constantly adapt to emerging technology as it becomes available. This is particularly the case with cutting-edge innovations in robotics, artificial intelligence and ubiquitous systems. Furthermore, organisations of the future would invest heavily in mediation that can be customised to various consumer groups (namely Generation Z, Generation Y and increasingly senior travellers). This future direction would place significant focus on automation and self-service technologies as mediators within current experiences to adapt to wider consumer trends. However, such a move would bring with it a host of management challenges for the sector.

From an operational standpoint, such an approach would call for further focus on dedicated expertise in-house within tourism organisations to manage and maintain their technology provision. While this may sound commonplace, a number of authors have already indicated a

Figure 1 Future directions for technological mediation in experiential tourism

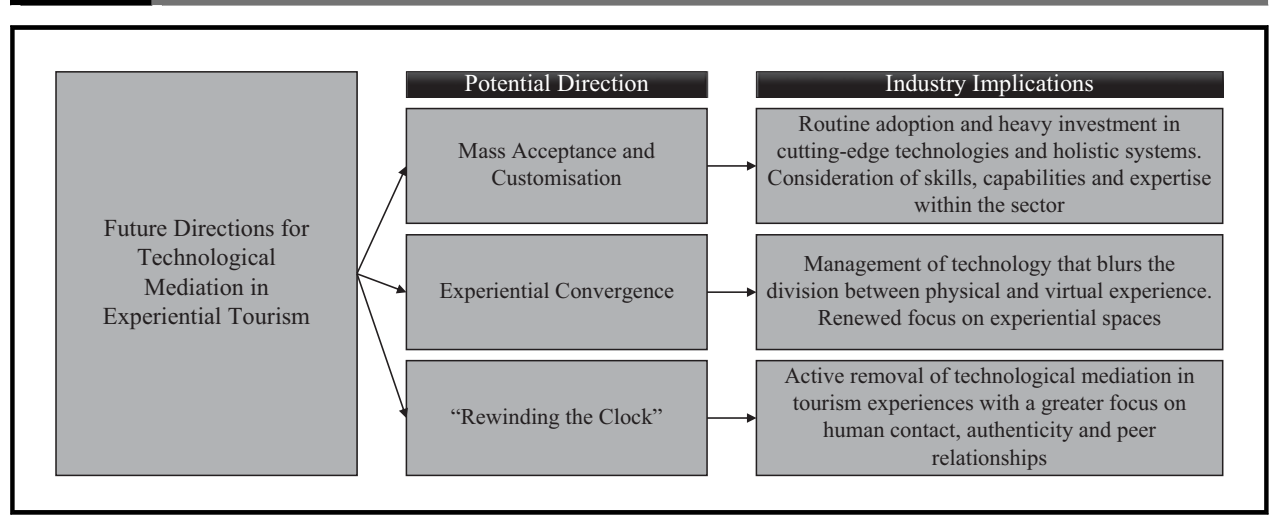

PAGE 122 JOURNAL OF TOURISM FUTURES $\mid$ VOL. 5 NO. 22019 
skills gap in tourism with regards to attracting and retaining technology specialists (Baum, 2006; Hojeghan and Esfangareh, 2011; Maurer, 2015). As such, a future challenge for the industry would not only be adapting to the changing technological landscape but also to ensure that the tourism workforce has the skills to react to these developments. Such a shift may encourage further outsourcing of technological expertise and a need for enhanced collaboration with stakeholders at various stages of the tourism supply chain (such as strengthening links between technology designers, manufacturers, suppliers, businesses and users).

In line with a need to consider expertise and capabilities, the industry of the future may need to consider the direction of business expenditure, namely, considering heavy investment not on individual platforms but on collective interfaces with the most potential for customisation. For example, in a museum setting, future strategies may shift from purchasing distinct touchpoints (each with different capabilities and levels of maintenance) to designing interlinked holistic systems which can be simultaneously updated, customised and managed internally. Conversely, a key future priority may also involve viewing the process of technology upgrading as cyclical rather than periodic. While such an approach would indeed have a high initial cost, the long-term maintenance implications and consistency-benefits to the visitor experience could be substantial.

\section{Experiential convergence}

A second potential route for the industry could involve further experiential convergence. As a "middle ground" of the two other directions discussed in this paper, this route can already be seen developing in the industry now. From this perspective, the divide between the physical and digital tourism experience would continue to blur. As a result, future tourism activity is likely to see a merging of tangible and technological landscapes within the travel experience. This direction would require tourism organisations to further invest in technologies which complement or extend the work of the human resource and move towards hybridisation of experiences. This route aligns closely to the rapidly proliferating literature in experiential co-creation in which technology can be seen as a tool to support customer involvement, engagement and dialogue within the tourism experience (Campos et al., 2015; Frochot and Batat, 2013). Examples of this could involve growth in geo-location systems that can guide visitors within locations and encourage active participation in the wayfinding. As identified by Skinner et al. (2018), activities such as geocaching are particularly well-placed to use technology to engage broader audiences and add additional layers to the experience. In shifting this perspective into the future, tourism businesses may consider the operational potential of technological mediators that most effectively act as co-creative tools.

A particularly interesting area that would align closely with this direction, is a renewed focus on multi-sensory engagement and hybridised "experiencescapes" (Mossberg, 2008; O'Dell, 2007). Tourism providers of the future may focus more on the environmental aspects of their experience and reframe their experiential spaces so that travellers seamlessly move between tangible and intangible opportunities. Examples of this are already emerging in the industry, where technology is being used to add sensory dimensions to traditionally static experiences. A project that illustrated this trend was the Sensorium exhibition at Tate Britain in London. This temporary exhibition brought classic artworks from the collection and invited designers, innovators and technologists to add technology-based touchpoints linked to each artwork. Innovations in sound, lighting and sensation were added in an attempt to engage the multiple senses of visitors and engage individuals more deeply with the artwork (Davis, 2015). While an isolated example, future tourism operators may continue to utilise technology to add additional sensory layers to the travel experience.

\section{Rewinding the clock}

A third route perhaps less travelled in current discussions on technological mediation would be to effectively "rewind the clock" and consider removing technology from certain experiences. Many would argue that this is an unachievable goal in a constantly connected digital landscape; however, there is an argument for returning, at least to some extent, to simpler tourism experiences that focus on human contact, interaction and authentic dialogue. In contrast to the routes suggested previously, this future scenario would require a bold stance from tourism managers to shun technological interfaces in favour of the human resource. If we reflect on a typical tourism experience, 
rarely will the entire visitor journey be completely technology free. This seems a radical departure now but perhaps there is an opportunity in returning to an experience which is mediated purely by people. Such a move would reignite the significance of personal connections, peer-to-peer contact and a sense of communitas in future tourism experiences. While of course, elements of this exist now, it is quite a transformational thought to imagine entire experiences as being technology free.

Critics may argue that this is just fallacy, that it is impossible to rewind the clock and detach from technology. However, as the works of Dickinson et al. (2016) and Neuhofer and Ladkin (2017) have begun to suggest, disconnection from the digital world does hold an appeal for certain travellers. Such moves would indicate that even if we are now digital natives, perhaps future travellers may choose to avoid technological mediation and actively pursue experiences that provide solace from connectivity and virtual interactions. Termed by Li et al. (2018) as digital-free tourism, the concept is growing in tourism scholarship for the potential benefits and opportunities of limiting technological mediation in certain spaces. Equally, this stance poses some interesting yet challenging questions for practitioners in tourism who may, in the future, need to examine their value propositions and question what would happen if they removed the technology altogether. Undeniably, basic utilities and back-office IT systems are paramount, but for customer-facing technologies, could they be reduced, stripped back or returned to service personnel? The more we think about how much of the tourism experience can now be mediated by technology, the more we realise that experiences have become increasingly automated. While these undoubtedly have implications for efficiency (both financially and for time-saving), has this rapid development begun to compromise the deeper level meaning or significance of tourism experiences? From a futures perspective, perhaps the most intriguing prospect for the industry is to consider how we can use technology more selectively or remove it from certain environments.

\section{Conclusion}

This paper sought to consider three potential directions for the future of technological mediation in tourism experiences. Considering rapid and progressive technological development, tourism businesses may elect to follow one of the routes identified within this paper and adapt their practices to accommodate the shifting landscape. A mass acceptance and customisation strategy would see organisations routinely adopting and investing heavily in cutting-edge technologies in an attempt to accept new innovations. An alternative direction could involve the industry engaging in experiential convergence, whereby organisations manage technological mediation that blurs the division between the physical and virtual experience. Finally, tourism businesses may elect to "rewind the clock" by actively removing layers of technological mediation within the tourism experience. Each direction brings its own challenges and complexities, however, only with open and future-orientated discussions can the industry begin to strategically plan for the inevitable growth of technological capabilities.

While these are individual viewpoints at this stage, there is already evidence of such directions emerging in the industry. As technology has become firmly embedded into the social fabric of travel and tourism, a future-orientated discussion is not only timely but necessary. Despite being drawn from an individual, subjective viewpoint, the directions identified in this paper will hopefully encourage debate and provoke further discussion as to the future role technology may play as a mediator in tourism experiences, and the inherent challenges for the sector in reacting to this phenomenon.

\section{References}

Alford, P. and Clarke, S. (2009), "Information technology and tourism: a theoretical critique", Technovation, Vol. 29 No. 9, pp. 580-7.

Barrutia, J.M. and Gilsanz, A. (2009), "e-Service quality: overview and research agenda", International Journal of Quality and Service Sciences, Vol. 1 No. 1, pp. 29-50.

Baum, T. (2006), "Reflections on the nature of skills in the experience economy: challenging traditional skills models in hospitality", Journal of Hospitality and Tourism Management, Vol. 13 No. 2, pp. 124-35.

Benckendorff, P., Sheldon, P. and Fesenmaier, D. (2014), Tourism Information Technology, 2nd ed., CABI Publishing, Wallingford. 
Buhalis, D. and Law, R. (2008), "Progress in information technology and tourism management: 20 years on and 10 years after the internet - the state of eTourism research", Tourism Management, Vol. 29 No. 4, pp. 609-23.

Buonincontri, P., Morvillo, A., Okumus, F. and van Niekerk, M. (2017), "Managing the experience co-creation process in tourism destinations: empirical findings from Naples”, Tourism Management, Vol. 62 No. 1, pp. 264-77.

Campos, A.C., Mendes, J., do Valle, P.O. and Scott, N. (2015), "Co-creation of tourist experiences: a literature review", Current Issues in Tourism, Vol. 21 No. 4, pp. 369-400.

Chathoth, P.K., Ungson, G.R., Harrington, R.J. and Chan, E.S.W. (2016), "Co-creation and higher order customer engagement in hospitality and tourism services", International Journal of Contemporary Hospitality Management, Vol. 28 No. 2, pp. 222-45.

Coussement, M. and Teague, T. (2013), "The new customer-facing technology: mobile and the constantlyconnected consumer”, Journal of Hospitality and Tourism Technology, Vol. 4 No. 2, pp. 177-87.

Davis, N. (2015), “Don't just look - smell, feel, and hear art. Tate's new way of experiencing paintings", The Guardian Newspaper, pp. 8-9, available at: www.theguardian.com/artanddesign/2015/aug/22/ tate-sensorium-art-soundscapes-chocolates-invisible-rain (accessed 22 August 2015).

Dickinson, J.E., Hibbert, J.F. and Filimonau, V. (2016), "Mobile technology and the tourist experience: (dis) connection at the campsite", Tourism Management, Vol. 57 No. 1, pp. 193-201.

Frochot, I. and Batat, W. (2013), Marketing and Designing the Tourist Experience, Goodfellow Publishers Limited, Oxford.

Gombault, A., Allal-Chérif, O. and Décamps, A. (2016), "ICT adoption in heritage organizations: crossing the chasm", Journal of Business Research, Vol. 69 No. 11, pp. 5135-40.

Gretzel, U. and Jamal, T. (2009), "Conceptualizing the creative tourist class: technology, mobility, and tourism experiences”, Tourism Analysis, Vol. 14 No. 4, pp. 471-81.

Haddouche, H. and Salomone, C. (2018), "Generation Z and the tourist experience: tourist stories and use of social networks", Journal of Tourism Futures, Vol. 4 No. 1, pp. 69-79.

Hojeghan, S.B. and Esfangareh, A.N. (2011), "Digital economy and tourism impacts, influences and challenges", Procedia - Social and Behavioral Sciences, Vol. 19 No. 1, pp. 308-16.

Hvass, K.A. and Munar, A.M. (2012), "The takeoff of social media in tourism", Journal of Vacation Marketing, Vol. 18 No. 2, pp. 93-103.

Jennings, G. and Weiler, B. (2005), "Mediating meaning: perspectives on brokering quality tourism experiences", in Jennings, G. and Nickerson, N. (Eds), Quality Tourism Experiences, Butterworth-Heinemann, Oxford, pp. 58-78.

Jung, T., Chung, N. and Leue, C. (2015), "The determinants of recommendations to use augmented reality technologies: the case of a Korean theme park”, Tourism Management, Vol. 49 No. 1, pp. 75-86.

Li, J., Pearce, P.L. and Low, D. (2018), "Media representation of digital-free tourism: a critical discourse analysis", Tourism Management, Vol. 69 No. 1, pp. 317-29.

Lu, J., Mao, Z., Wang, M. and Hu, L. (2015), “Goodbye maps, hello apps? Exploring the influential determinants of travel app adoption”, Current Issues in Tourism, Vol. 18 No. 11, pp. 1059-79.

Mathis, E.F., Kim, H., Uysal, M., Sirgy, J.M. and Prebensen, N.K. (2016), "The effect of co-creation experience on outcome variable", Annals of Tourism Research, Vol. 57 No. 1, pp. 62-75.

Maurer, C. (2015), "Digital divide and its potential impact on cultural tourism", in Katsoni, V. (Ed.), Cultural Tourism in a Digital Era. Springer Proceedings in Business and Economics, Springer, Cham, pp. 231-41.

Minghetti, V. and Buhalis, D. (2010), "Digital divide in tourism", Journal of Travel Research, Vol. 49 No. 3, pp. 267-81.

Morosan, C. and DeFranco, A. (2016), "Co-creating value in hotels using mobile devices: a conceptual model with empirical validation", International Journal of Hospitality Management, Vol. 52 No. 1, pp. 131-42.

Mossberg, L. (2008), "Extraordinary experiences through storytelling", Scandinavian Journal of Hospitality and Tourism, Vol. 8 No. 3, pp. 195-210. 
Neuhofer, B. and Ladkin, A. (2017), "(Dis)connectivity in the travel context: setting an agenda for research", in Schegg, R. and Stangl, B. (Eds), Information and Communication Technologies in Tourism 2017, Springer International Publishing, Cham, pp. 347-59.

Neuhofer, B., Buhalis, D. and Ladkin, A. (2014), "A typology of technology-enhanced tourism experiences", International Journal of Tourism Research, Vol. 16 No. 4, pp. 340-50.

O'Dell, T. (2007), "Tourist experiences and academic junctures", Scandinavian Journal of Hospitality and Tourism, Vol. 7 No. 1, pp. 34-45.

Peña, A.P., Jamilena, D.F. and Molina, M.R. (2014), "Value co-creation via information and communications technology", The Service Industries Journal, Vol. 34 No. 13, pp. 1043-59.

Rey, F.B. and Casado-Neira, D. (2013), "Participation and technology: perception and public expectations about the use of ICTs in museums", Procedia Technology, Vol. 9 No. 1, pp. 697-704.

Scarles, C., Casey, M. and Treharne, H. (2016), "Enriching the visitor experience: augmented reality and image recognition in tourism", in Scerri, M. and Hui, L. (Eds), CAUTHE 2016: The Changing Landscape of Tourism and Hospitality: The Impact of Emerging Markets and Emerging Destinations, Blue Mountains International Hotel Management School, Sydney, pp. 1172-84.

Schumann, J.H., Wünderlich, N.V. and Wangenheim, F. (2012), "Technology mediation in service delivery: a new typology and an agenda for managers and academics”, Technovation, Vol. 32 No. 2, pp. 133-43.

Skinner, H., Sarpong, D. and White, G.R.T. (2018), "Meeting the needs of the millennials and generation Z: gamification in tourism through geocaching", Journal of Tourism Futures, Vol. 4 No. 1, pp. 93-104.

tom Dieck, M. and Jung, T. (2017), "Value of augmented reality at cultural heritage sites: a stakeholder approach", Journal of Destination Marketing \& Management, Vol. 6 No. 2, pp. 110-7.

Tussyadiah, I.P. (2014), "Toward a theoretical foundation for experience design in tourism", Journal of Travel Research, Vol. 53 No. 5, pp. 543-64.

Tussyadiah, I.P. and Fesenmaier, D. (2009), "Mediating tourist experiences", Annals of Tourism Research, Vol. 36 No. 1, pp. 24-40.

Wan, C.K.B. (2018), "Flourishing through smart tourism: experience patterns for co-designing technologymediated traveller experiences", The Design Journal, Vol. 21 No. 1, pp. 163-72.

Wang, D., Xiang, Z. and Fesenmaier, D.R. (2014), "Adapting to the mobile world: a model of smartphone use", Annals of Tourism Research, Vol. 48 No. 1, pp. 11-26.

Younes, G., Kahil, R., Jallad, M., Asmar, D., Elhajj, I., Turkiyyah, G. and Al-Harithy, H. (2017), "Virtual and augmented reality for rich interaction with cultural heritage sites: a case study from the Roman Theater at Byblos", Digital Applications in Archaeology and Cultural Heritage, Vol. 5 No. 1, pp. 1-9.

Zhang, H., Lu, Y., Wang, B. and Wu, S. (2015), "The impacts of technological environments and co-creation experiences on customer participation”, Information \& Management, Vol. 52 No. 4, pp. 468-82.

Zhang, T.C., Lu, C. and Kizildag, M. (2017), "Engaging generation Y to co-create through mobile technology", International Journal of Electronic Commerce, Vol. 21 No. 4, pp. 489-516.

\section{About the author}

Dr Ellis Urquhart is Lecturer in Tourism Management at the Business School at Edinburgh Napier University, UK. He specialises in visitor attraction management, co-creative experience design and technological mediation in the heritage sector and the wider attraction environment. Ellis teaches and supervises tourism management students at both undergraduate and postgraduate levels at Edinburgh Napier University, in addition to overseas programmes delivered in Switzerland and Hong Kong. He currently reviews for a range of tourism publications and sits on the editorial board of the Journal of Tourism Futures. Dr Ellis Urquhart can be contacted at: e.urquhart@napier.ac.uk

For instructions on how to order reprints of this article, please visit our website:

www.emeraldgrouppublishing.com/licensing/reprints.htm

Or contact us for further details: permissions@emeraldinsight.com 